\title{
Dampak Moderasi Perilaku Knowledge Sharing dan Teamwork terhadap Produktivitas Dosen
}

\author{
Fenri Abraham Stevi Tupamahu; Merryl Pelamonia; Wiclif. S. Pinoa \\ Program Studi Pendidikan Ekonomi FKIP Universitas Pattimura \\ Program Studi Pendidikan Geografi FKIP Universitas Pattimura \\ Jl. Ir. M. Putuhena, Poka, Tlk. Ambon, Kota Ambon, Maluku \\ f2dtupamahu@gmail.com
}

Article received: May 2020; revised : Desember 2020 ; accepted : January 2021

DOI : 10.17977/um025v5i12020p12

\begin{abstract}
This study aims to: (1) examine the effect of teamwork work activities on the productivity of lecturers at the Faculty of Social Sciences, Pattimura University; and (2) determine the role of moderating knowledge sharing behavior between the effects of teamwork work activities on the productivity of lecturers at the Faculty of Social Sciences, Pattimura University. This type of research is causal research. The unit of analysis in this study was the individual lecturer at the Social Sciences Department of the Faculty of Teacher Training and Education at Pattimura University. The total number of lecturers at the Faculty of Social Sciences, Pattimura University is 72 people. The sampling method uses nonprobability methods, sampling using purposive sampling technique. Determination of the sample is based on judgment (judgment sampling). The results of the study explain that knowledge sharing behavior is not a variable that directly affects the productivity of Social Sciences lecturers at the Faculty of Social Sciences, Pattimura University, but interacts with teamwork.
\end{abstract}

Keywords: teamwork; knowledge sharing; lecturer productivity

\begin{abstract}
Abstrak: Abstrak: Penelitian ini bertujuan: (1) menguji pengaruh aktivitas kerja teamwork terhadap produktivitas dosen Jurusan IPS FKIP Universitas Pattimura; dan (2) menentukan peran moderasi perilaku knowledge sharing antara pengaruh aktivitas kerja teamwork terhadap produktivitas dosen Jurusan IPS FKIP Universitas Pattimura. Jenis penelitian ini merupakan riset causal. Unit analisis pada penelitian ini adalah individu dosen Jurusan IPS FKIP Universitas Pattimura. Keseluruhan jumlah dosen Jurusan IPS FKIP Universitas Pattimura sebanyak 72 orang. Metode pengambilan sampel menggunakan metode nonprobabilitas, pengambilan sampel menggunakan teknik purposive sampling. Penentuan sampel berdasarkan pertimbangan (judgment sampling). Hasil penelitian menjelaskan perilaku knowledge sharing tidak sebagai variabel yang mempengaruhi langsung terhadap produktivitas dosen Jurusan IPS FKIP Universitas Pattimura, namun berinteraksi terhadap teamwork.
\end{abstract}

Kata kunci: teamwork; knowledge sharing; produktivitas dosen

Perkembangan ilmu pengetahuan, teknologi, informasi, peningkatan dinamika aspek sosial, budaya serta dinamisasi kondisi ekonomi global mendorong peran perguruan tinggi semakin kompleks dalam tugas serta fungsinya guna mengembangkan kemampuan dan meningkatkan kualitas sumber daya manusia suatu bangsa dan negara. Perguruan tinggi sebagai lembaga pendidikan tinggi dalam melaksanakan tugas tri dharma yakni, pengajaran, pengabdian, dan penelitian dihadapkan pada tuntutan peningkatan 
mutu dan produktivitas yang sustainable. Hal tersebut mendasari tekanan pencapaian mutu maksimal serta pencapaian kinerja civitas akademika secara menyeluruh dan konsisten dalam implementasi tugas tri dharma. Kondisi tersebut menuntut dukungan kualitas sumber daya manusia, terutama dosen yang memiliki kualifikasi dan unjuk kerja sesuai dengan kesesuaian kebutuhan perkembangan dan tantangan jaman.

Dosen sebagai pilar utama perguruan tinggi, dalam tugas dan fungsi serta sebagai sumber daya perguruan tinggi memiliki nilai tinggi dalam setiap aktivitas dan karya ciptanya (Budiyarto, 2018). Konsekuensi dari hal tersebut setiap saat dosen cenderung memiliki beban tugas yang terus meningkat dan relatif lebih kompleks. Namun dosen sebagai pendidik dengan tugas dan fungsinya selalu mengupayakan, menyesuaikan kompetensi untuk terus bekerja serta berkinerja maksimal, walaupun dihadapkan pada banyak kelemahan dan tantangan. Hasil-hasil kajian empiris membuktikan berbagai determinan hasil kerja dosen, Mangkunegara (2020) menjelaskan hasil kerja dosen dipengaruhi oleh motivasi berprestasi dan kepemimpinan rektor. Hasil penelitian Rahayu (2015) membuktikan bahwa hasil kerja dosen dipengaruhi oleh masa kerja dan kepuasan. Pramudyo (2010) membuktikan peningkatan hasil kerja dosen memerlukan beberapa hal antara lain, motivasi yang tinggi, kompetensi yang memadai, kepemimpinan yang baik dan lingkungan kerja yang mendukung dosen untuk dapat melaksanakan tugasnya. Kenyataannya pendidikan tinggi di Indonesia saat ini dihadapkan pada keselarasan perkembangan ilmu pengetahuan, teknologi, informasi, tuntutan dunia kerja yang semakin kompleks, serta tekanan persaingan global, kondisi ini membutuhkan paradigma serta relevansi pelaksanaan tugas dengan berorientasi output serta outcame perguruan tinggi yang bermutu.

Relevansi pengelolahan perguruan tinggi dalam tantangan dan dinamika lingkungan berorientasi pada output serta outcame yang berdaya saing, mengharuskan civitas akademika, terutama dosen memiliki produktivitas tinggi dalam melaksanakan tugas. Fakta konsekuensi kondisi tersebut, berdampak pada kecenderungan dinamika kerja semakin kompleks serta beban tugas dosen semakin tinggi. Tentama et al (2019) mengungkapkan dosen dihadapkan pada komplektivitas tugas, baik bidang akademik, non akademik, maupun administrasi. Kondisi tuntutan tugas yang kompleks tersebut cenderung kontradiktif dengan fakta tiap perguruan tinggi relatif memiliki komposisi sumber daya yang bervariasi, sehingga terdapat kecenderungan mengalami masalah produktivitas pada dosen. Kondisi tersebut juga dialami oleh dosen Jurusan Ilmu Pengetahuan Sosial (IPS) Fakultas Keguruan Dan Ilmu Pendidikan (FKIP) Universitas Pattimura. Walaupun relatif dengan keterbatasan sarana prasarana pemenuhan kewajiban dalam tugas tri dharma meliputi pendidikan dan pengajaran, penelitian, dan pengabdian kepada masyarakat harus dilakukan setiap semester. Dosen Jurusan IPS FKIP Universitas Pattimura juga dibebankan melakukan tugas-tugas tambahan misalnya, kegiatan ilmiah, konsisten dalam pencapaian publikasi terindeks (misalnya, publikasi ilmiah terindeks Sistem Indeksasi dan Sitasi Indonesia maupun internasional), terlibat dalam asosiasi, atau gugus tugas, dan terlibat dalam struktur organisasi. Fakta semua tugas/pekerjaan yang dilakukan Dosen Jurusan IPS FKIP Universitas Pattimura berkaitan dengan standar, tuntutan jumlah dan kualitas kerja, pencapaian point yang terkait dengan remunerasi, dan tenggat waktu kerja.

Fakta tingginya kuantitas beban kerja dosen Jurusan IPS FKIP Universitas Pattimura berpotensi menyebabkan kelelahan, jenuh, penurunan energi dan terjadi stres kerja, hal tersebut diasumsikan berdampak pada kecenderungan penurunan produktivitas kerja. Gillespie et al (2013) menjelaskan bahwa beban kerja yang berlebihan akan menyebabkan tugas menjadi tertunda, mengurangi produktivitas kerja. Produktivitas merupakan akumulasi ukuran pencapaian kerja yang mencakup efektivitas dan efisiensi, produktivitas dapat jelaskan sebagai hasil kerja kongkrit (satuan atau ukuran output) oleh tiap-tiap individu ataupun kelompok, dalam suatu aktivitas kerja selama jangka waktu tertentu. Secara umum produktivitas dalam prespektif organisasi dipengaruhi oleh berbagai faktor, terutama faktor manajemen. Wijaya (1990:19) dalam Budiyarto (2018) menjelaskan beberpa faktor yang mempengaruhi tinggi rendahnya produktivitas dosen antara lain: (1) pendidikan; (2) tingkat penghasilan; (3) jaminan sosial; (4) disiplin kerja; (5) sikap mental dan etika kerja; dan (6) motivasi kerja kerja. Sedarmayanti (2009) menyatakan bahwa ada beberapa faktor yang mempengaruhi produktivitas kerja diantaranya: (1) tindakan konstruktif; (2) percaya pada diri sendiri; (3) memiliki rasa cinta terhadap pekerjaan; (4) 
mempunyai pandangan ke depan; (5) mampu menyelesaikan pekerjaan dan dapat beradaptasi dengan perubahan lingkungan; (6) mempunyai kontribusi positif terhadap lingkungan; (7) memiliki kekuatan untuk mewujudkan potensi yang dimiliki; dan (8) semangat dan motivasi kerja yang mampu mendorong dalam bekerjasama menyelesaikan pekerjaan.

Konsep produktivitas dijelaskan dalam dua perspektif: pertama, prespektif individu dan organisasi, produktivitas dilihat sebagai hasil dari kepribadian individu yang muncul dalam bentuk sikap mental, menyiratkan keinginan dan upaya mereka yang selalu berusaha untuk meningkatkan kualitas hidup. Prespektif kedua, organisasi prespektif ini memandang dalam hal hubungan teknis antara input, output, kualitas, dan kuantitas (Alvesson \& Sveningsson, 2018). Produktivitas berkaitan dengan faktor manajemen terutama aspek perilaku organisasi yang meliputi, budaya organisasi, iklim organisasi, kepemimpinan, aspek motivasi, komunikasi, hubungan interpersonal, dinamika kelompok, serta manajemen konflik. Pertiwi (2017) membuktikan bahwa tingkat produktivitas dipengaruhi oleh disiplin kerja dalam hal kehadiran, ketaatan pada aturan kerja dan ketaatan pada standar kerja.

Dalam konteks manajemen institusi pendidikan tinggi, produktivitas dapat dipandang sebagai, output dari seberapa baik menggabungkan sumber daya seperti, tenaga kerja (tenaga pendidik dan tenaga kependidikan), keterampilan, peralatan, kekayaan intelektual, kemampuan manajerial. Produktivitas dosen dapat dijelaskan sebagai ukuran kemampuan individu dosen untuk menghasilkan sesuatu dari tugas dan pekerjan yang diberikan oleh lembaga dengan cara membandingkan rasio antara hasil yang dicapainya dalam tugas tri dharma Perguruan Tinggi dengan peningkatan kualitas lembaga (Budiyarto, 2018). Produktivitas kerja dosen adalah capaian hasil dari segenap potensi dosen dengan mendayagunakan sumber daya yang dimilikinya dihubungkan dengan waktu, kuantitas dan kualitas dalam melaksanakan tugasnya menjalankan tri dharma perguruan tinggi (Purwanti et al., 2019).

Konsistensi produktivitas saat ini menjadi kewajiban bagi dosen Jurusan IPS FKIP Universitas Pattimura. Namun fakta kondisi beban kerja yang relatif tinggi, sumberdaya yang variatif terutama dalam hal daya dukung fasilitas atau sarana prasarana yang beragam pada tiap unit institusi cenderung menjustifikasi bahwa pencapaian produktivitas dosen relatif kompleks. Secara empiris hasil-hasil kajian membuktikan variasi determinan produktivitas antara lain, Budiyarto (2018) membuktikan motivasi kerja, disiplin kerja, diklat, dan komunikasi organisasi berpengaruh signifikan terhadap produktivitas dosen. Hasil penelitian Tentama et al (2019) menyimpulkan bahwa beban kerja dan stres kerja secara simultan mempengaruhi produktivitas dosen. Pelaksanaan tugas pokok dosen di lingkup Jurusan IPS FKIP Universitas Pattimura relatif belum didukung dengan fasilitas yang lengkap, namun dalam aktivitas kerja dosen Jurusan IPS FKIP Universitas Pattimura mengimplementasikan budaya kerja yang mendukung pencapaian produktivitas maksimal dengan kesesuaian daya dukung sarana prasarana relatif minim. Hasil kajian Tupamahu \& Pinoa (2019) mengungkapkan bahwa dosen Jurusan IPS FKIP Universitas Pattimura memiliki kemampuan relationhip dan berkumunikasi dengan baik guna mendukung aktivitas pelaksanaan tugas tri dharma yang semakin kompleks. Hal tersebut mendasari implementasi aktivitas perilaku kerja dosen di lingkup Jurusan IPS FKIP Universitas Pattimura yang memiliki karakteristik kerja kolektif atau teamwork. Penyelesaian tugas Tri Dharma dilakukan dengan mengutamakan koordinasi, kerja sama atau pembagian tugas dibandingkan kerja individu.

Aktivitas kerja teamwork diterima dan teraplikasi dalam berbagai proses penyalesaian tugas tri dharma maupun tugas tambahan oleh dosen Jurusan IPS FKIP Universitas Pattimura dan dipandang cocok dengan dinamika tugas serta kondisi lingkungan kerja Jurusan IPS FKIP Universitas Pattimura. Kerja tim atau teamwork didefinisikan oleh Scarnati (2001) dalam Mailisa Safitri \& Shabri (2012) sebagai proses yang memungkinkan sesorang untuk mencapai hasil yang luar biasa. Kerja tim atau teamwork adalah suatu kelompok kerja yang formal terdri atas orang-orang yang bekerja bersamasama untuk mencapi tujuan kelompok yang umum (De Janasz \& Forret, 2008). Aktivitas teamwork merupakan proses bekerja secara kolaboratif dengan sekelompok orang untuk mencapai suatu tujuan (Agarwal \& Adjirackor, 2016).

Harris dan Harris (1996) dalam Mailisa Safitri \& Shabri, (2012) menjelaskan bahwa teamwork memiliki tujuan bersama atau tujuan dimana anggota tim dapat mengembangkan keefektifan dan 
hubungan timbal balik untuk mencapai tujuan tim. Aktivitas kerja secara tim (teamwork) secara umum relevan dalam tuntutan pencapaian keberhasilan kerja yang maksimal, aktivitas teamwork berkaitan dengan berbagai aspek organisasional serta beragam ciri keterkaitannya dengan produktivitas. McShane and Von Glinow, (2015) menjelaskan indikator teamwork meliputi, cooperating (bekerjasama), coordinating (koordinasi), communicating (komunikasi), comforting (kenyamanan), conflict resolving (pemecahan masalah). Aktivitas kerja teamwork merupakan salah satu faktor yang menentukan produktivitas.

Hasil-hasil penelitian empiris membuktikan pengaruh teamwork terhadap produktivitas antara lain, hasil penelitian empiris Agarwal \& Adjirackor (2016) mengungkapkan bahwa teamwork membawa manfaat dalam hal produktivitas yang lebih tinggi. Penelitian Maeni (2019) membuktikan bahwa teamwork berpengaruh terhadap produktivitas kerja. Namun tiap organisasi memiliki budaya, dinamika dan karakteristik kerja yang beragam, hal ini mendasari ambivalensi bahwa teamwork mutlak sebagai determinan langsung terhadap produktivitas. Hasil kajian Arif et al (2017) menjustifikasi ambivalensi tersebut dengan membuktikan bahwa teamwork, tidak berpengaruh secara langsung terhadap produktivitas, namun dimediasi oleh loyalitas. Hasil-hasil penelitian tersebut secara umum mendasari asumsi bahwa pada prinsipnya perilaku kerja secara teamwork berpotensi sebagai determinan positif, baik secara langsung maupun tidak langsung terhadap tingkat produktivitas.

Proses kerja secara teamwork oleh dosen dalam rangka pelaksanaan tugas tri dharma merupakan proses bekerja secara kolaboratif, berbagi beban kerja serta tanggung jawab bersama dalam melaksanakan tugas pengajaran, penelitian dan pengabdian kepada masyarakat. Secara teknis aktivitas kerja teamwork berkontribusi pada keteraturan kerja, keteraturan administrasi, efisiensi waktu kerja, pembagian tanggung jawab kerja yang efektif bagi dosen dalam hal pelaksanaan tugas tri dharma. Pencapaian produktivitas dosen tidak hanya dipengaruhi oleh kerja teratur atau tersistimatis secara administratif, namun perlu aktualisasi kesesuaian perilaku kerja, kreativitas dan inovasi dalam melaksanakan tugas tri dharma. Pencapaian produktivitas dosen di lingkup Jurusan IPS FKIP Universitas Pattimura merupakan aktivitas yang memiliki keterkaitan sumberdaya organisasi dan aktualisasi perilaku organisasi yang dinamis. Pelaksanaan tugas tugas tri dharma Perguruan Tinggi oleh dosen sangat membutuhkan dukungan sumberdaya, budaya organisasi maupun penyesuaian perilaku organisasi yang efektif. Ciri aktualisasi pelaksanaan tugas-tugas tri dharma maupun tugas tambahan oleh dosen Jurusan IPS FKIP Universitas Pattimura sebagai institusi pendidikan yang berbasis pengetahuan (knowledge-base organization) didukung sustainable pengembangan keilmuan/pengetahuan individu maupun kelompok dosen. Pengetahuan merupakan sumberdaya institusi pendidikan yang dikelolah secara efektif menjadi faktor penting dan menunjang kualitas serta kemajuan institusi pendidikan.

Knowledge sharing merupakan perilaku yang sangat penting untuk menunjang perkembagan organisasi saat ini, termasuk institusi perguruan tinggi (Latupapua, 2019). Cheng et al (2009) menjelaskan knowledge sharing merupakan perilaku individu membagi apa yang telah mereka pelajari dan mentransfer apa yang telah mereka ketahui, kepada mereka yang memiliki kepentingan bersama dan telah menemukan pengetahuan yang bermanfaat. Knowledge sharing merupakan sebuah mekanisme interaksi di mana pengetahuan ditransmisikan dari satu pihak kepihak yang lain (Kuo, 2013). Berbagi pengetahuan (knowledge sharing) merupakan budaya interaksi sosial, komponen, tahapan krusial dalam proses knowledge management, menjadi isu dalam kajian-kajian manajemen organisasi, termasuk manajemen institusi pendidikan tinggi dengan kondisi tuntutan pengelolahan yang semakin kompleks. Secara empiris dibuktikan urgensi perilaku knowledge sharing dalam aktivitas kerja dosen antara lain, hasil penelitian Masoumeh (2014) membuktikan proses meningkatkan pengetahuan dan pengalaman dosen dapat dilakukan melalui berbagi pengetahuan. Hasil penelitian Balik (2019) membuktikan peran penting perilaku knowledge sharing yang terbukti memediasi aspek internal dosen dan pemahaman filosofi, norma atau nilai-nilai yang dianut dalam institusi pendidikan dan sebagai kekuatan sosial, serta terbukti relevan sebagai azas knowledge management guna meningkatkan kinerja dosen dalam tugas tri dharma yang kompleks sebagai konsekuensi memasuki era revolusi industri 4.0. Hasil-hasil kajian empiris menjustifikasi knowledge sharing sebagai perilaku penting guna meningkatkan pengetahuan, pengalaman dosen serta relevan dengan tuntutan pelaksanaan tugas tri dharma Perguruan Tinggi saat ini. 
Perilaku knowledge sharing di institusi pendidikan dipandang sebagai pengerak dinamisasi proses penciptaan pengetahuan, distribusi pengetahuan, dan aplikasi pengetahuan. Aktivitas knowledge sharing merupakan mekanisme sosial dosen di lingkup Jurusan IPS FKIP Universitas Pattimura bersifat kolektif dalam hal bertukar saran, informasi, pengalaman dan keahlian yang relevan serta mentransformasikan pengetahuan menjadi parktek aktual. Aktualisasi perilaku knowledge sharing mendukung relevansi aktivitas kerja dosen di lingkup Jurusan IPS FKIP Universitas Pattimura sesuai dengan karakteristik serta tuntutan mutu pelaksanaan tugas tri dharma. Perilaku knowledge sharing relevan dengan perilaku kerja teamwork, yang diimplementasikan oleh dosen di lingkup Jurusan IPS FKIP Universitas Pattimura, temuan Witherspoon et al (2013) menguatkan argumen tersebut, dengan menyatakan bahwa knowledge sharing lebih mudah diaplikasikan dalam model kerja kolektif dibandingkan individu. Hasil penelitian Liao (2006) mendasari postulat bahwa kinerja akan meningkat apabila anggota organisasi melakukan knowledge sharing, dalam arti berbagi informasi, perkembangan ilmu, praktek yang efektif, wawasan, pengalaman, preferensi, hal-hal yang dipelajari.

Implementasi aktivitas kerja teamwork dan perilaku knowledge sharing memiliki interaksi atau keterkaitan dalam proses penyelesaian tugas, interaksi tersebut merupakan karakteristik kombinasi atau mekanisme kerja strategis dan dipandang penting serta dimaknai oleh dosen Jurusan IPS FKIP Universitas Pattimura. Investigasi penelitian ini guna pembuktian secara empiris keterkaitan atau interaksi aktivitas kerja teamwork dengan implementasi perilaku knowledge sharing sebagai suatu mekanisme kerja strategis dan pengaruhnya terhadap pencapaian produktivitas dosen Jurusan IPS FKIP Universitas Pattimura. Tujuan penelitian ini adalah untuk: (1) menguji pengaruh aktivitas kerja teamwork terhadap produktivitas dosen Jurusan IPS FKIP Universitas Pattimura; dan (2) menentukan peran moderasi perilaku knowledge sharing antara pengaruh aktivitas kerja teamwork terhadap produktivitas dosen Jurusan IPS FKIP Universitas Pattimura.

\section{METODE}

\section{Desain Penelitian}

Jenis penelitian ini merupakan riset causal, yang menjelaskan hubungan kausal atau hubungan sebab akibat yang terjadi antara variabel bebas dan variabel terikat serta variabel pemoderasi dan merupakan model riset hypothesis testing. Dimensi waktu penelitian ini dilakukan dalam satu kurun waktu dengan melibatkan banyak sampel (cross sectional). Unit analisis pada penelitian ini adalah individu dosen Jurusan IPS FKIP Universitas Pattimura. Keseluruhan jumlah dosen Jurusan IPS FKIP Universitas Pattimura sebanyak 72 orang. Metode pengambilan sampel menggunakan metode nonprobabilitas, pengambilan sampel menggunakan teknik purposive sampling. Penentuan sampel berdasarkan pertimbangan (judgment sampling), dengan kriteria yakni: (1) dosen tetap PNS Universitas Pattimura; dan (2) dosen berstatus aktif dalam melaksanakan tugas Tri Dharma. Berdasarkan kriteria sampling dan kelengkapan data, jumlah sampel yang dianalisis dalam penelitian ini sebanyak 46 orang. Jenis data dalam penelitian ini adalah primer dan merupakan data kualitatif yang kemudian dikuantitatifkan dengan menggunakan skala likert. Proses pengumpulan data menggunakan teknik pengumpulan data survei, dengan menggunakan cara penyebaran instrumen kuisioner.

\section{Definisi Operaional Variabel dan Pengukurannya}

Variabel teamwork (T) didefinisikan sebagai proses bekerja dan memecahkan masalah secara kolaboratif dalam sekelompok dosen guna pelaksanaan tugas Tri Dharma maupun tugas tambahan. Indicator variabel teamwork dalam penelitian ini diadopsi dari konsep yang dikemukakan oleh McShane and Von Glinow, (2015) meliputi: cooperating (bekerjasama), coordinating (koordinasi), communicating (komunikasi), comforting (kenyamanan), conflict resolving (pemecahan masalah). Variabel knowledge sharing (KS) didefinisikan sebagai perilaku individu dosen membagi pengalaman, pengetahuan yang telah dipelajari dan mentransfer apa yang telah mereka ketahui, kepada kelompok dosen yang memiliki kepentingan bersama dan penyelesaian tugas Tri Dharma maupun tugas tambahan. Indikator 
variabel knowledge sharing dalam penelitian ini adalah, mengumpulkan pengetahuan, menyumbangkan pengetahuan, berbagi pengalaman, dan berbagi informasi.

Variabel perilaku produktivitas dosen (PD) adalah, capaian hasil dari segenap potensi dosen dengan mendayagunakan sumber daya yang dimilikinya dihubungkan dengan waktu, kuantitas dan kualitas dalam melaksanakan tugasnya menjalankan tridharma perguruan tinggi. Indicator variabel produktivitas dosen (PD) dalam penelitian ini diadopsi dari Purwanti et al (2019) meliputi, pencapaian kualitas kerja tri dharma dan tugas tambahan, pencapaian kuantitas kerja tri dharma dan tugas tambahan, pemanfaatan waktu, pengembangan diri serta pemanfaatan sarana dan teknologi. Pengukuran variabel menggunakan skala Likert, mulai dari skala 1 (sangat tidak setuju) sampai dengan skala 5 (sangat setuju).

\section{Teknik Analisis Data}

Model analisis penelitian ini mengambarakan kerangka pengujian antar variabel, secara konseptual model analisis dijelaskan pada Gambar 1 berikut ini.

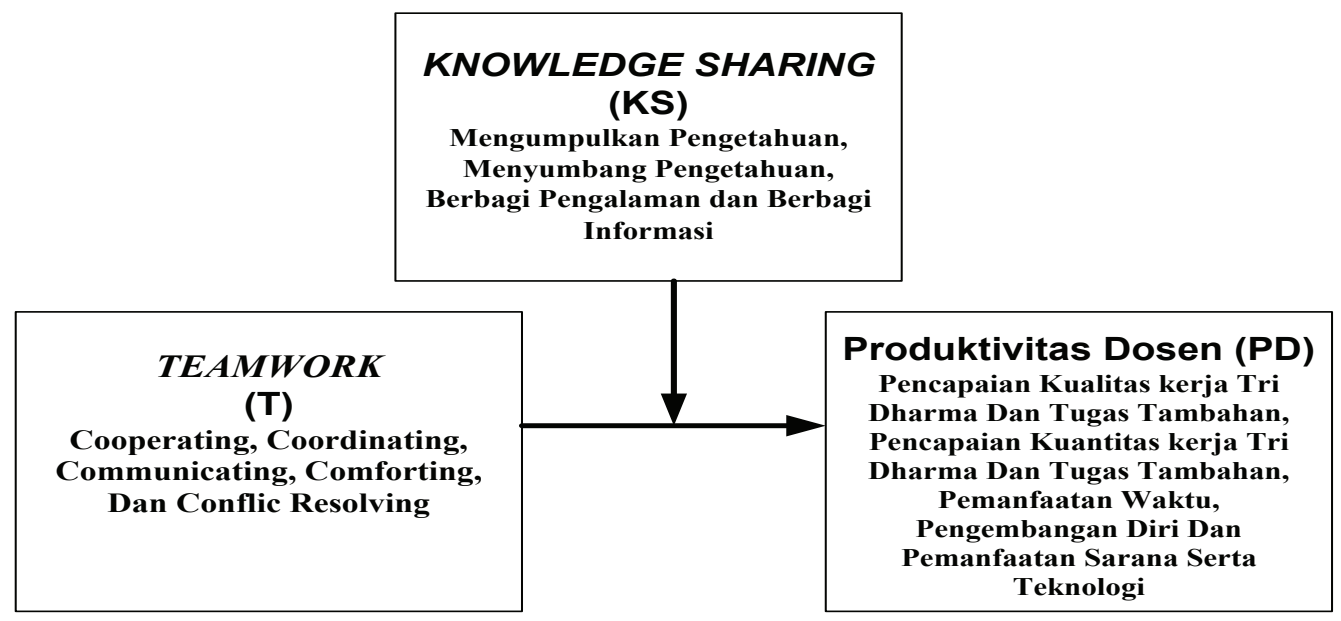

\section{Gambar 1 Model Analisis}

Analisis data menggunakan metode statistik Moderated Regression Analysis. Persamaan moderated regression adalah:

$$
\mathrm{PD}=\alpha+\beta 1 \mathrm{~T}+\beta 2 \mathrm{~T}^{*} \mathrm{KS}+\varepsilon
$$

$$
\begin{aligned}
& \text { Keterangan: } \\
& \begin{array}{ll}
\mathrm{PD} & =\text { Produktivitas Dosen } \\
\mathrm{T} & =\text { Teamwork } \\
\mathrm{KS} & =\text { Knowledge Sharing } \\
\alpha & =\text { Konstanta } \\
\varepsilon \quad & =\text { Error } \\
\beta & =\text { Koefisien regresi }
\end{array}
\end{aligned}
$$

\section{HASIL DAN PEMBAHASAN}

Uji instrumen dengan menggunakan Uji validitas dan reliabilitas, membuktikan bahwa nilai nilai koefisien Product Moment (r) indikator lebih besar dari 0.5 dan nilai cronbach alpha lebih besar dari 0.6, hasil tersebut membuktikan bahwa instrumen penelitian reliabel. Uji normalitas data pada penelitian dilakukan dengan melihat kecenderungan sebaran data terhadap garis regresi pada grafik normal 
probability plot dengan. Hasil perhitungan menjelaskan grafik normal probability plot (penjelasan pada Gambar 2), menunjukkan bahwa titik-titik data relatif di sekitar atau menyebar mengikuti garis diagonal, dengan demikian sebaran data dapat dijustifikasi berdistribusi normal.

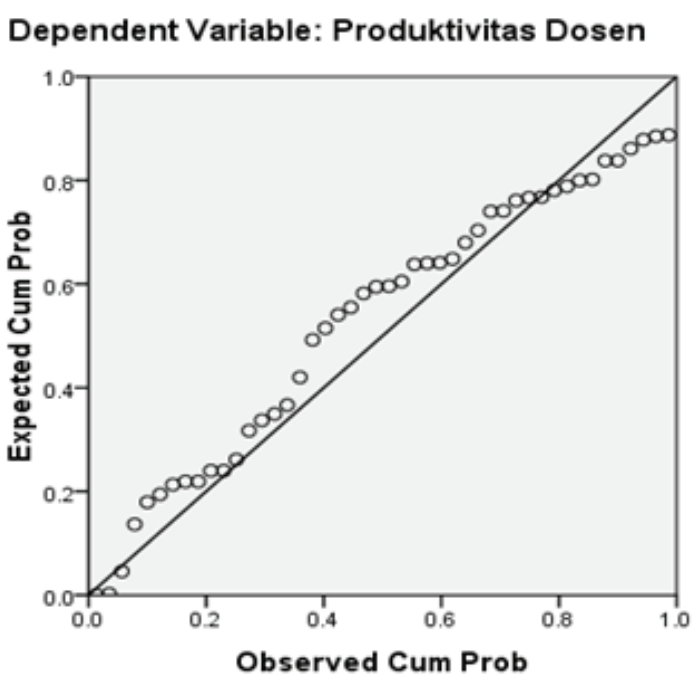

Gambar 2 Normal Probability Plot

Analisis deskriptif mengambarkan karakteristik demografi, gambaran Jabatan Fungsional responden dan jenjang pendidikan terakhir, dijelaskan pada Tabel 1 berikut ini.

Tabel 1 Deskripsi Responden

\begin{tabular}{|c|c|c|c|}
\hline No & Deskripsi Responden & Jumlah (Orang) & Persentase (\%) \\
\hline \multirow{3}{*}{1} & Jenis Kelamin & & \\
\hline & Pria & 25 & 54.34 \\
\hline & Wanita & 21 & 45.65 \\
\hline \multirow{9}{*}{2} & & Umur & \\
\hline & 33 tahun -36 tahun & 2 & 4.34 \\
\hline & 37 tahun -40 tahun & 10 & 21.73 \\
\hline & 41 tahun -44 tahun & 17 & 36.96 \\
\hline & 45 tahun -48 tahun & 8 & 17.39 \\
\hline & 49 tahun -52 tahun & 4 & 8.69 \\
\hline & 53 tahun - 56 tahun & 2 & 4.34 \\
\hline & 57 tahun - 60 tahun & 1 & 2.17 \\
\hline & 61 tahun - 64 tahun & 2 & 4.34 \\
\hline \multirow{5}{*}{3} & Jabatan Fungsional & & \\
\hline & Guru Besar & 1 & 2.17 \\
\hline & Lektor Kepala & 7 & 15.21 \\
\hline & Lektor & 32 & 69.56 \\
\hline & Asisten Ahli & 6 & 13.04 \\
\hline \multirow{3}{*}{4} & Jenjang Pendidikan & & \\
\hline & Strata Tiga (S3) & 22 & 47.83 \\
\hline & Strata Dua (S2) & 24 & 52.17 \\
\hline
\end{tabular}


Hasil analisis deskriptif menjelaskan gambaran responden terbanyak berjenis kelamin pria yakni sebanyak 25 orang, namun secara gender jumlah tersebut relatif atau hampir sama dengan jumlah responden wanita yakni 21 orang. Responden terbanyak pada range umur 41 tahun - 44 tahun yakni sebanyak 17 orang atau $36.96 \%$ dari keseluruhan responden, gambaran ini menjelaskan mayoritas dosen Jurusan IPS FKIP Universitas Pattimura tergolong usia muda dan produktif. Berdasarkan Jabatan Fungsional mayoritas responden memiliki Jabatan Fungsional Lektor, yakni sebanyak 32 orang atau $69.56 \%$ dari keseluruhan responden. Berdasarkan tingkat pendidikan terakhir responden terbanyak memiliki tingkat pendidikan terakhir Strata Dua (S2), yakni sebanyak 24 orang, namun jumlah ini relatif atau sebanding dengan jumlah responden yang memiliki tingkat pendidikan Strata Tiga (S3) yakni sebanyak 22 orang. Gambaran tersebut menjelaskan dosen Jurusan IPS FKIP Universitas Pattimura memiliki tingkat pendidikan yang sesuai peraturan dan relevansi kemampuan akademik guna menjalankan tugas pokok.

Hasil uji regresi moderasi, menggunakan model regresi pure moderator, model ini menjelaskan variabel moderator $\left(\mathrm{T}^{*} \mathrm{KS}\right)$ tidak berhubungan dengan variabel produktivitas dosen $(\mathrm{PD})$ dan prediktor tidak berfungsi sebagai variabel independen, namun variabel moderator $\left(\mathrm{T}^{*} \mathrm{KS}\right)$ berinteraksi dengan variabel prediktor teamwork (T). Hasil perhitungan regresi moderasi dijelaskan pada Tabel 2 berikut ini.

Tabel 2 Hasil Uji Regresi Moderasi

\begin{tabular}{ccccc}
\hline Variabel & $\begin{array}{c}\text { Standardized } \\
\text { Coefficients (B) }\end{array}$ & t hitung & Sig. & Keterangan \\
\hline Constant & 0.815 & & & \\
\hline Teamwork (T) & 0.324 & 3.034 & 0.004 & Signifikan \\
\hline Moderator (T*KS) & 0.009 & 4.180 & 0.000 & Signifikan \\
\hline R & & 0.928 & & \\
\hline R Square & 0.862 & & & \\
\hline F hitung & 133.869 & & & \\
\hline Sign. F & 0.000 & & & \\
\hline
\end{tabular}

Model regresi berdasarkan hasil analisis dengan bantuan program SPSS 23 dapat dibentuk persamaan Moderated Regression Analysis sebagai berikut:

$$
\mathrm{PD}=0.815+0.324 \mathrm{~T}+0.009 \mathrm{~T} * \mathrm{KS}
$$

Adapun interpretasi dari persamaan tersebut adalah:

$\beta 1=0.324$ nilai parameter atau koefisien regresi $\beta 1$ menjelaskan bahwa setiap peningkatan variabel teamwork (T) diindikasikan (1) cooperating (bekerjasama). (2) coordinating (koordinasi), (3) communicating (komunikasi), (4) comforting (kenyamanan), (5) conflict resolving (pemecahan masalah), maka produktivitas dosen (PD) akan meningkat sebesar nilai koefisien regresi $\beta 1$ atau peningkatan produktivitas dosen (PD) dibutuhkan variabel teamwork $(\mathrm{T})$ sebesar 0.324 .

$\beta 2=0.009$ nilai parameter atau koefisien regresi $\beta 2$ menjelaskan bahwa variabel moderasi yakni knowledge sharing diwakili oleh indikator mengumpulkan pengetahuan, menyumbangkan pengetahuan, berbagi pengalaman, dan berbagi informasi terbukti mempengaruhi dalam arti berinteraksi serta menguatkan pengaruh teamwork terhadap produktivitas dosen (PD) sebesar nilai koefisien regresi $\beta 2$ atau knowledge sharing berinteraksi serta menguatkan pengaruh teamwork terhadap produktivitas dosen sebesar 0.009 .

Nilai "R" sebesar 0.928 nilai ini membuktikan hubungan (korelasi) antara variabel teamwork (T) dan dampak variabel moderasi terhadap produktivitas dosen (PD) sebesar 92.8\%. nilai "R2" sebesar 
0.862, nilai ini menjelaskan determinasi (sumbangan) variabel teamwork (T) dan dampak variabel moderasi terhadap produktivitas dosen (PD) sebesar $86.2 \%$, sedangkan $13.8 \%$ dijelaskan oleh faktor lain yang tidak dijelaskan dalam model.

Variabel teamwork (T) memiliki nilai t statistik/hitung sebesar 3.034 dan nilai sig 0.004, nilai tersebut menjelaskan pembuktian signifikan pada level $0.05(\rho<0.05)$. Dengan demikian terbukti bahwa, terima Ha dan tolak $\mathrm{H} 0$ atau hipotesis 1 diterima, hasil uji ini menjelaskan bahwa variabel teamwork berpengaruh signifikan terhadap produktivitas dosen Jurusan IPS FKIP Universitas Pattimura. Nilai t statistik/hitung variabel moderasi sebesar 4.180 dan nilai sig 0.000 , nilai tersebut menjelaskan pembuktian signifikan pada level $0.05(\rho<0.05)$. Hasil ini membuktikan terima Ha dan tolak H0 atau hipotesis 2 diterima, hasil uji tersebut menjelaskan realisasi perilaku knowledge sharing berinteraksi serta menguatkan pengaruh teamwork terhadap produktivitas dosen Jurusan IPS FKIP Universitas Pattimura.

Penelitian ini membuktikan teamwork berpengaruh terhadap produktivitas dosen Jurusan IPS FKIP Universitas Pattimura. Penelitian ini membuktikan bahwa realisasi teamwork diproxi dalam hal cooperating (bekerjasama), coordinating (koordinasi), communicating (komunikasi), comforting (kenyamanan), conflict resolving (pemecahan masalah) mempengaruhi produktivitas dosen meliputi, pencapaian kualitas kerja tri dharma dan tugas tambahan, pencapaian kuantitas kerja tri dharma dan tugas tambahan, pemanfaatan waktu, pengembangan diri serta pemanfaatan sarana dan teknologi.

Penelitian ini mengungkapkan aktivitas teamwork merupakan implementasi dosen Jurusan IPS FKIP Universitas Pattimura bekerja sama sehingga kerja lebih efektif, koordinasi lebih baik sehingga dosen mampu bekerja secara efisien dan harmonis, menjalin komunikasi lebih baik, penyampaian informasi secara lengkap. Realisasi aktivitas teamwork membangun kenyamanan dalam hal keadaan psikologis yang sehat dan positif dalam bekerja. Aktivitas teamwork mengatur potensi konflik dan mengelola kemampuan serta motivasi untuk menyelesaikan disfungsional ketidaksetujuan antara anggota tim dosen. Implementasi aktivitas teamwork terbukti sebagai pendorong produktivitas dosen Jurusan IPS FKIP Universitas Pattimura.

Hasil penelitian ini mengklaim eksistensi keterkaitan individu dan organisasi dalam kelompok kerja/teamwork sebagai sebagai determinan produktivitas dosen. Penelitian ini mengungkapkan implementasi teamwork yang efektif merupakan akitivitas dosen dalam kohesivitas kelompok kerja yang medinamisasi aspek-aspek cooperating, coordinating, communicating, comforting, conflict resolving sebagai karakteristik kerja strategis dan merupakan determinan produktivitas dosen. Hasil penelitian ini menguatkan konsep prespektif individu, organisasi dan produktivitas (Alvesson \& Sveningsson, 2018), sebagai aktivitas individu dosen yang muncul dalam bentuk sikap kerja kolektif, dinamika serta keterkaitan dalam kerja kelompok yang mempengaruhi output kerja. Hasil penelitian ini mendukung hasil kajian Agarwal \& Adjirackor, (2016) dan Maeni (2019) yang menyimpulkan teamwork mempengaruhi produktivitas.

Hasil penelitian membuktikan perilaku knowledge sharing sebagai variabel moderasi atau interaksi mempunyai pengaruh positif antara teamwork dengan produktivitas dosen. Knowledge sharing yang diproxi dalam hal, mengumpulkan pengetahuan, menyumbangkan pengetahuan, berbagi pengalaman, dan berbagi informasi terbukti berinteraksi serta memperkuat pengaruhl terhadap produktivitas dosen. Penelitian ini menjelaskan perilaku knowledge sharing tidak sebagai variabel yang mempengaruhi langsung terhadap produktivitas dosen Jurusan IPS FKIP Universitas Pattimura, namun berinteraksi terhadap teamwork. Dampak moderasi perilaku knowledge sharing sebagai interaksi pada aktivitas teamwork terbukti membentuk mekanisme kerja startegis yang relevan dalam komplektivitas tugas dosen.

Penelitian ini menjelaskan dampak moderasi perilaku knowledge sharing sebagai kombinasi interaksi sosial dalam konteks mengumpulkan pengetahuan, menyumbangkan pengetahuan, berbagi pengalaman, dan berbagi informasi dengan model kerja kolektif atau teamwork. Efek moderasi perilaku knowledge sharing membentuk proses teamwork lebih dinamis, dan kebersatuan kelompok, menguatkan efektivitas implementasi azas manajemen dalam bekerja. Dampak moderasi perilaku knowledge sharing sebagai pendorong pengembangan intelektual dosen dan garansi keselarasan kerja dengan perkembangan 
cepat ilmu pengetahuan. Dampak moderasi knowledge sharing terbukti berkontribusi dan mendukung pengembangan wawasan, pengalaman, keilmuan/pengetahuan maupun pengembangan kemampuan memecakan masalah, pengembangan kompetensi individu maupun kelompok dosen Jurusan IPS FKIP Universitas Pattimura serta dapat mengaplikasikan dalam pelaksanaan tugas pokok. Hal tersebut merupakan basis pendorong efektifitas dan efisiensi manajemen Universitas Pattimura sebagai institusi pendidikan yang berbasis pengetahuan (knowledge-base organization).

Hasil penelitian mengungkapkan model kerja teamwork merupakan faktor pendorong produktivitas dosen, namun dalam konteks penyelesaian tugas tri dharma yang berbasis pengetahuan, efek moderasi knowledge sharing terbukti menguatkan pengaruh teamwork terhadap produktivitas dosen. Penelitian ini membuktikan dampak moderasi perilaku knowledge sharing dalam interaksi teamwork sebagai pendorong produktivitas dosen merupakan mekenisme interaksi sosial dalam hal berbagi pengetahuan. Penelitian ini mengungkapkan bukti peran integrasi atau kombinasi perilaku interaksi sosial dengan model kerja kolektif (teamwork) sebagai determinan produktivitas. Penelitian mengungkapkan knowledge sharing merupakan perilaku penting bagi dosen dan manajemen institusi pendidikan tinggi, hasil penelitian ini relevan dengan hasil penelitian Liao (2006), Masoumeh (2014), Balik (2019). Hasil penelitian ini mendukung hasil kajian Latupapua (2019) yang menyatakan bahwa perguruan tinggi merupakan organisasi berbasis pengetahuan yang mana terjadi pertukaran pengetahuann antar komponen yang memberi andil bagi terciptanya iklim berbagi pengetahuan antar dosen maupun mahasiswa. Penelitian ini membuktikan perilaku knowledge sharing cocok/relevan dengan implementasi model kerja kolektif, hasil penelitian ini mendukung hasil temuan Witherspoon et al (2013). Penelitian ini menjelaskan interaksi perilaku knowledge sharing yang merupakan interaksi sosial dosen dengan teamwork yang merupakan modal kerja sebagai input produktivitas dosen.

\section{SIMPULAN}

Teamwork berpengaruh terhadap produktivitas dosen Jurusan IPS FKIP Universitas Pattimura. Semakin baik realisasi aktivitas teamwork dalam hal cooperating (bekerjasama), coordinating (koordinasi), communicating (komunikasi), comforting (kenyamanan), conflict resolving (pemecahan masalah) mempengaruhi peningkatan produktivitas dosen meliputi, pencapaian kualitas kerja tri dharma dan tugas tambahan, pencapaian kuantitas kerja tri dharma dan tugas tambahan, pemanfaatan waktu, pengembangan diri serta pemanfaatan sarana dan teknologi. Dampak moderasi perilaku knowledge sharing sebagai pendorong pengembangan intelektual dosen dan garansi keselarasan kerja dengan perkembangan cepat ilmu pengetahuan. Knowledge sharing yang diproxi dalam hal, mengumpulkan pengetahuan, menyumbangkan pengetahuan, berbagi pengalaman, dan berbagi informasi terbukti berinteraksi serta memperkuat pengaruh teamwork terhadap produktivitas dosen.

Model kerja teamwork merupakan faktor pendorong produktivitas dosen, namun dalam konteks penyelesaian tugas tri dharma yang berbasis pengetahuan, efek moderasi knowledge sharing terbukti menguatkan pengaruh teamwork terhadap produktivitas dosen. Teamwork dan knowledge sharing merupakan faktor maupun perilaku penting bagi aktivitas kerja dosen dan manajemen institusi pendidikan tinggi, diharapkan teamwork menjadi model kerja dan didukung SOP guna menjamin mutu kerja. Knowledge sharing harus dipedomani secara meyeluruh sebagai budaya akademik. Hal tersebut perlu direalisakikan melalui peran aktif pimpinan mengembangkan wawasan dan integritas ilmiah, melalui fasilitasi pusat kajian ilmu, kegiatan mimbar ilmiah, diskusi ilmiah non formal, ruang kebebasan berpikir kritis-analitis, rasional serta obyektif oleh civitas akademik.

\section{DAFTAR RUJUKAN}

Agarwal, S., \& Adjirackor, T. (2016). Impact of Teamwork on Organizational Productivity in Some Selected Basic Schools in the Accra Metropolitan Assembly. European Journal of Business, Economics and Accountancy.

Alvesson, M., \& Sveningsson, S. (2018). Organizational culture and change. In Changing Organizational Culture. https://doi.org/10.4324/9781315688404-3 
Arif, S., Amboningtyas, D., Hasiholan, L. B., \& Fathoni, A. (2017). Pengaruh Kompensasi Dan Team Work Terhadap Produktivitas Kerja Karyawan Melalui Loyalitas Karyawan Pada Cv. Mawar Semarang. Maharaja Agrasen Institute of Management and Technology Journal of IT \& Management.

Balik, D. (2019). Pengaruh Karakteristik Individu Dan Budaya Kerja Terhadap Kinerja Dosen Muda Universitas Kristen Indonesia Maluku Melalui Perilaku Knowledge Sharing ( Kajian Model Determinan Kinerja Dosen Dalam Memasuki Era Revolusi Industri 4 . 0 ). Prosiding Seminar Nasional \& Call Paper Prodi Pendidikan Ekonomi FKIP Universitas Pattimura, 109-125.

Budiyarto, A. (2018). Manajemen Sumber Daya Manusia Dan Produktivitas Dosen. Jurnal Administrasi Pendidikan. https://doi.org/10.17509/jap.v25i1.11577

Cheng, M.-Y., Ho, J., \& Lau, P. (2009). Knowledge Sharing In Academic Institutions: A Study Of Multimedia University Malaysia. Electronic Journal of Knowledge Management.

De Janasz, S. C., \& Forret, M. L. (2008). Learning the art of networking: A critical skill for enhancing social capital and career success. Journal of Management Education. https://doi.org/10.1177/1052562907307637

Gillespie, G. L., Bresler, S., Gates, D. M., \& Succop, P. (2013). Posttraumatic Stress Symptomatology among Emergency Department Workers following Workplace Aggression. Workplace Health \& Safety. https://doi. org/10.1177/216507991306100603

Harsono, H. (2012). Fasilitas Peranan Sarana dan Prasarana terhadap Produktivitas Kerja UKM di Kota Magelang. Jurnal Bina Praja. https://doi.org/10.21787/jbp.04.2012.237-242

Kuo, T. H. (2013). How expected benefit and trust influence knowledge sharing. Industrial Management and Data Systems. https://doi.org/10.1108/02635571311322766

Latupapua, C. V. (2019). Efek Mediasi Perilaku Kewargaan Organisasi Dalam Hubungan Antara Kepercayaan Organisasional Dan Perilaku Berbagi Pengetahuan Dosen (Suatu Tinjauan Dalam Menghadapi Era Industri 4.O). Prosiding Seminar Nasional \& Call Paper Prodi Pendidikan Ekonomi FKIP Universitas Pattimura, $1-12$.

Liao, L. F. (2006). A Learning Organization Perspective on Knowledge-Sharing Behavior And Firm Innovation. Human Systems Management.

Maeni, E. S. (2019). Pengaruh Tim Dan Loyalitas Karyawan Terhadap Produktivitas Kerja Pada Proyek PT. Newton The Hybrid Park Bandung. Journal of Chemical Information and Modeling.

Mailisa Safitri, H., \& Shabri, M. (2012). Pengaruh Gaya Kepemimpinan, Kerjasama Tim, Dan Gaya Komunikasi Terhadap Kepuasan Kerja Serta Dampaknya Terhadap Kinerja Pegawai Pada Sekretariat Daerah Kota Sabang. Pascasarjana Universitas Syiah Kuala.

Mangkunegara, A. P. (2020). Transformational Rector Leadership In Building Achievement Motivation And Lecturer Performance. Test Engineering and Management.

Masoumeh, K. (2014). The Main Factors Influencing Knowledge Sharing in Private universities of Malaysia. Interdisplicary Journal of Contemporary Research in Business.

McShane, S. L., \& Von Glinow, M. A. (2015). Organizational Behavior - Emerging Realities for the Workplace Revolution. In McGraw-Hill. https://doi.org/10.1017/CBO9781107415324.004

Pertiwi, F. (2017). Pengaruh Disiplin Kerja Terhadap Produktivitas Kerja Pegawai Negeri Sipil Di Kantor Dinas Perindustrian Perdagangan Koperasi Dan Umkm Provinsi Kalimantan Timur. EJournal Administrasi Negara.

Pramudyo, A. (2010). Analisis Faktor-Faktor Yang Mempengaruhi Kinerja Dosen Negeri Pada Kopertis Wilayah V Yogyakarta. Jurnal Bisnis : Teori Dan Implementasi.

Purwanti, A. R., Hidayat, N., \& Sutisna, E. (2019). Peningkatan Produktivitas Kerja Dosen Melalui Pengembangan Efektivitas Sistem Informasi Manajemen Dan Budaya Organisasi. Jurnal Manajemen Pendidikan. https://doi. org/10.33751/jmp.v7i2.1333

Rahayu, B. (2015). Faktor- Faktor Yang Mempengaruhi Kinerja Dosen Fakultas Ekonomi Universitas Darul 'Ulum Jombang. 1, 141-153. 
Sedarmayanti. (2009). Sumber Daya Manusia dan Produktivitas Kerja: Sedarmayanti - Belbuk.com. Mandar Maju. Tentama, F., Missasi, V., \& Nasywa, N. (2019). Work Productivity In Lecturer: Case In The Private University In Yogyakarta, Indonesia. International Journal of Scientific and Technology Research.

Tupamahu, Fenri Abraham Stevi \& Pinoa, W. (2019). Pengaruh Karakteristik Individu dan Budaya Kerja Terhadap Kinerja Dosen Melalui Perilaku Knowledge Sharing. Maranatha Economics \& Business Conference, 71.

Witherspoon, C. L., Bergner, J., Cockrell, C., \& Stone, D. N. (2013). Antecedents Of Organizational Knowledge Sharing: A meta-Analysis And Critique. Journal of Knowledge Management. https://doi. org/10.1108/13673271311315204 